\title{
СКРИНІНГ ЗНАНЬ ПРО ЛАЙМ-БОРЕЛІОЗ БАТЬКІВ ДІТЕЙ, ЯКІ ЗАЗНАЛИ НАПАДІВ КЛІЩІВ
}

\author{
Тернопільський державний медичний університет ім. І.Я. Горбачевського
}

\begin{abstract}
Мета роботи - оцінити обізнаність щодо Лаймбореліозу батьків тих дітей, які зазнали нападів кліщів на території Тернопільської області, та встановити частоту природного зараження B. burgdorferi sensu lato кліщів, відібраних від мешканців області.

Пацієнти і методи. Опитуванням було охоплено 207 батьків. Усі опитані дали відповіді на запитання уніфрікованої міжнародної анкети-опитувальника. На основі анкетних даних проаналізовано та оцінено поінфрормованість батьків дітей, що зазнали нападів кліщів, щодо бореліозу, а також обгрунтовано доцільність розширення їх знань про хворобу Лайма та інші інфрекції, пов'язані з укусом кліщів.
\end{abstract}

Результати досліджень. Зі слів батьків і дітей, напади кліщів сталися у 38 (18,4 \%) потерпілих дітей в межах села, у 94 (45,4 \%) - міста, у лісі - у 48 (23,2 \%), на лузі - в 11 (5,3 \%); 16 (7,7\%) - не пам'ятають укусів кліща протягом життя.

Найчастішими місцями укусів пацієнти відзначили ділянку голови (50 осіб) та ніг (40). Укуси в руки, шию і тулуб ззаду згадувалися рідше - 24, 34, 21 і 25 випадків відповідно. На укуси в живіт вказали лише 24 особи, укуси в ділянку статевих органів - 4 дітей.

87,0 \% опитаних батьків не застосовують репелентів при вході в лісову зону, оглядають шкіру після повернення з лісу лише 33,6 \% опитаних.

70,0 \% членистоногих були видалені лікарями травмпункту Тернопільської обласної комунальної дитячої клінічної лікарні, стільки ж опитаних продезінфрікували місце укусу дезрозчином, решта кліщів видалено іншим способом.

Висновки. Дані опитування виявили низький відсоток (13,0 \%) застосування батьками репелентів при відвідуванні лісопаркових зон, нехтування оглядом шкірних покривів після повернення з лісу; недостатність санітарно-освітньої роботи серед батьків дітей, які зазнали нападів кліщів, низьку обізнаність із заходами профрілактики, правильним способом видалення членистоногих. Встановлено, що 12,3 \% іксодових кліщів, видалених від дітей, інфріковані В. burgdorferi sensu lato.
Ключові слова: Лайм-бореліоз, борелії, діагностика, кліщі, анкета-опитувальник, репеленти.

Хвороба Лайма (ЛБ, системний кліщовий бореліоз, Лайм-бореліоз, хронічна мігруюча еритема, кліщова еритема) - природно-осередкова трансмісивна хвороба, яка спричиняється бореліями (Borrelia burgdorferi) та проявляється мігруючою кільцеподібною еритемою, гарячкою, ураженням центральної і перифреричної нервової системи, серця й великих суглобів [1]. Західна Україна, в тому числі й Тернопільська область, $є$ ендемічним осередком ЛБ, оскільки розташована в зоні 3 родючими ґрунтами, помірним континентальним кліматом, лісними ландшафтами, що сприяє збереженню в природі основного резервуара борелій - іксодових кліщів. Території іксодових кліщових бореліозів виявлено в 57 населених пунктах 14 районів області та у м. Тернополі [2].

Мета роботи - оцінити обізнаність щодо Лаймбореліозу батьків дітей, які зазнали нападів кліщів на території Тернопільської області, та встановити частоту природного зараження B. burgdorferi sensu lato кліщів, відібраних від мешканців області.

Дані обстеження є реалізацією частини українськопольського проекту «Дослідження епідеміології, патогенезу, клініки та профрілактики бореліозу» науково-дослідницьких проектів Європейського Союзу [3].

\section{Пацієнти і методи}

Опитуванням було охоплено 207 батьків. Їхні діти віком від 1 до 15 років зазнали нападу кліщів на території Тернопільської області в період з травня по серпень 2017 року. Хлопчиків було 120, дівчаток - 87.

Усі опитані дали відповіді на запитання унісрікованої міжнародної анкети-опитувальника, в якій зазначили число та місця укусів кліщів, спосіб їх видалення, результати обстеження кліщів на наявність бореліозу, скарги дитини після зазначених укусів, застосування репелентів при вході в лісову зону та огляд шкірних покривів після повернення $з$ неї. На основі анкетних даних проаналізовано та оцінено поінформованість батьків, а також обґрунтовано 
доцільність розширення їх знань про хворобу Лайма та інш інфекції, пов'язані з укусом кліщів.

Встановлено, що 122 із 207 (58,9 \%) батьків дітей, які зазнали нападів кліщів, доставили останніх у центр із вивчення Лайм-бореліозу та інших інфекцій при ДВНЗ «Тернопільський державний медичний університет ім. І.Я. Горбачевського» МОЗ України [4]. Кліщів ідентифікували за допомогою стереомікроскопічної системи SEO, яка включає стереомікроскоп, кольорову цифррову камеру і фотоадаптер. Види кліщів розрізняли за допомогою прийнятих таблиць [5]. ДНК В. burgdorferi sensu lato (B. burgdorferi sensu stricto, B. afzelii та B. garinii визначали за допомогою ПЛР у режимі реального часу.
Результати досліджень та їх обговорення

Зі слів батьків і дітей, напади кліщів сталися у 38 (18,4 \%) потерпілих дітей в межах села, у 94 (45,4 \%) - міста; 48 (23,2 \%) -у лісі; 11 (5,3 \%) - на лузі ; 16 (7,7\%) - не пам'ятають укусів кліща протягом життя.

Серед німф, знятих з дітей, переважали особини молодшого (довжина 0,6-0,8 мм) і середнього (1,41,6 мм) віку.

Із 207 обстежених (4,8 \%) відмітили понад 3 укуси кліщами, одноразовий укус кліщем зазначили 167 (80,6 \%), дворазовий - 24 (11,6 \%), 3 і більше укусів мали місце у 10 випадках (табл. 1).

Таблиця 1

Дані опитування про укуси кліщів у дітей (згідно з міжнародним анкетним опитуванням)

\begin{tabular}{|c|c|c|c|}
\hline \multicolumn{2}{|r|}{ Характеристика укусу } & Число опитаних (n=207) & $\%$ \\
\hline \multirow{4}{*}{ 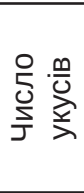 } & 1 раз & 167 & 81,2 \\
\hline & 2 рази & 24 & 11,6 \\
\hline & 3 і більше & 10 & 4,8 \\
\hline & Не мали жодного або не пам'ятають & 16 & 7,7 \\
\hline \multirow{8}{*}{ 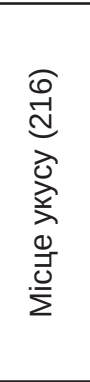 } & Руки & 24 & 11,1 \\
\hline & Ноги & 40 & 18,5 \\
\hline & \multirow{2}{*}{$\begin{array}{l}\text { Тулуб спереду } \\
\text { ззаду }\end{array}$} & 21 & 9,7 \\
\hline & & 19 & 8,8 \\
\hline & Голова & 50 & 23,1 \\
\hline & Шия & 34 & 15,7 \\
\hline & Живіт & 24 & 11,1 \\
\hline & Статеві органи & 4 & 1,9 \\
\hline \multirow{10}{*}{ 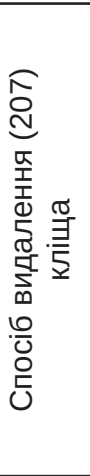 } & Видалив лікар & 153 & 73,9 \\
\hline & Видалила інша особа & 3 & 1,5 \\
\hline & Вирвав кліща пальцями & 9 & 4,3 \\
\hline & Видалив кліща простими рухами & 8 & 3,9 \\
\hline & Викрутив кліща & 10 & 4,8 \\
\hline & Зішкрябав нігтем & 1 & 0,5 \\
\hline & Полляв кліща дезінсрекційним розчином & 4 & 1,9 \\
\hline & Намазав олією & 4 & 1,9 \\
\hline & Продезінфрікував місце укусу & 170 & 82,1 \\
\hline & Інше (виліз сам) & 5 & 2,4 \\
\hline \multirow{8}{*}{ 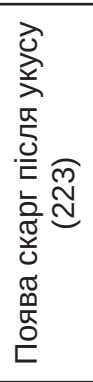 } & Зміна кольору шкіри в місці укусу кліщем і віддалених ділянках & 31 & 13,9 \\
\hline & Свербіж & 11 & 4,9 \\
\hline & Біль у суглобах & 3 & 1,3 \\
\hline & Запалення суглобів & 1 & 0,4 \\
\hline & Біль м'язів & 4 & 1,8 \\
\hline & Збільшення лімфровузлів недалеко від місця укусів & 9 & 4,0 \\
\hline & Гарячка & 12 & 5,4 \\
\hline & Відсутні & 152 & 68,2 \\
\hline
\end{tabular}


Найчастішими місцями укусів пацієнти відзначили ділянку голови (50 осіб) та ніг (40). Укуси в руки, шию і тулуб ззаду згадувалися рідше - 11,1, 15,7 і 8,8 \% випадків відповідно. На укуси в живіт вказали лише 24 особи.

Цікавими виявилися 2 випадки, коли із шкірних покривів було знято по 16 і 28 кліщів відповідно.

Слід зазначити, що 70,0 \% членистоногих були видалені лікарями травмпункту Тернопільської обласної комунальної дитячої клінічної лікарні, стільки ж опитаних продезінфрікували місце укусу дезрозчином, решта кліщів видалено іншим способом.

Найбільш частими скаргами дітей після укусу кліща, на які вказали батьки та діти, були підвищення температури тіла - 5,4 \%, свербіж - 4,9 \%, зміна кольору шкіри - 13,0 \%. Почервоніння шкіри (мігруючу еритему) відзначили 26 обстежених. Слід зазначити, що 68,2 \% опитаних не мали жодних скарг.

Вражає той фракт, що 87,0 \% опитаних батьків не застосовують репелентів при вході в лісову зону, оглядають шкіру після повернення з лісу лише 33,6 \% опитаних, а 19,8 \% - не оглядають ніколи (мал. 1).

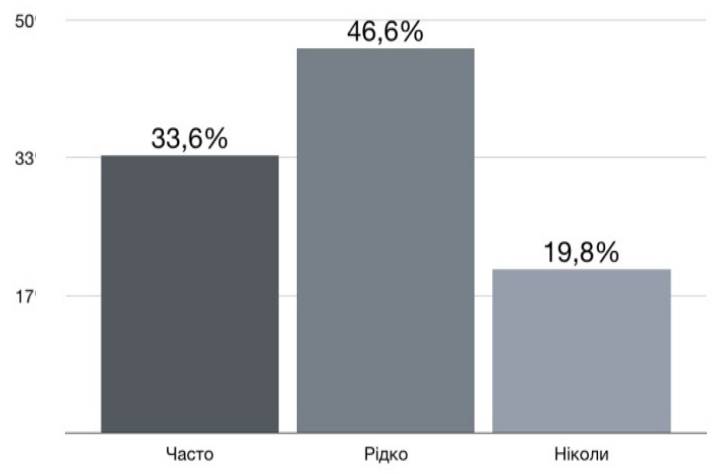

Мал. 1. Огляд шкірних покривів після повернення з лісу.

\section{Література}

1. Інфекційні хвороби у загальній практиці та сімейній медицині / за ред. М.А. Андрейчина. - Тернопіль: ТдМУ, Укрмедкнига, 2007. - 500 c.

2. Хвороба Лайма на Тернопільщині / Н.А. Васильєва, О.Л. Івахів, В.О. Качор [та ін.] // Інфекційні хвороби. - 2011. - № 2 - С. 50-53.

3. Шкільна М.І. Лайм-бореліоз у працівників лісових господарств Тернопільської області / М.І. Шкільна // Інфекційні хвороби. - 2016. - № 1 (83). - С. 36-40.

4. Частота виявлення борелій і анаплазми у кліщів, вилучених від мешканців Тернопільської області / М.А. Андрейчин, М.І. Шкільна, С.О. Никитюк [та ін.] // Епідеміологічні та клінічні ускладнення інфекційних і паразитарних хвороб у сучасних умовах: Тези всеукр.
Достатніми вважають власні знання та відомості засобів інфрормації щодо бореліозу 12,0 і 25,0 \% батьків, середніми - 17,6 та 20,9 \%, мінімальними - 22,4 і 18,9\%. I майже половина опитаних (48,0 і 35,2 \%) не володіють інфрормацією про дане захворювання.

Аналогічна ситуація щодо знань профрілактики Лаймбореліозу характерна і для інших верств населення, зокрема студентів Тернопільського національного педагогічного університету ім. В. Гнатюка та Тернопільського національного технічного університету ім. І. Пулюя $[6,7]$.

Усі досліджені кліщі належали до роду Ixodes (I. ricinus), $з$ них 75,0 \% німсри, 25,0 \% - дорослі особини. Із 122 досліджених кліщів 15 (12,3 \%) були іноріковані $B$. burgdorferi sensu lato. Отримані нами результати співзвучні з даними літератури, згідно з якими зараженість кліщів бореліями в Польщі складає 6,2 \%, у Білорусі - 9,4 \%, у Литві - $11 \%$ [8].

\section{Висновки}

1. Дані опитування виявили низький відсоток $(13,0$ \%) застосування батьками репелентів при відвідуванні лісопаркових зон та низьку частоту огляду шкірних покривів після повернення з лісу; недостатність санітарно-освітньої роботи серед батьків дітей, які зазнали нападів кліщів.

2. Дані опитування батьків і їх дітей, які зазнали нападу кліщів, свідчать про низьку обізнаність із заходами профрілактики, правильним способом видалення членистоногих і доцільністю обстеження останніх на інфікованість бореліями.

3. У дітей найчастішим місцем укусу є голова, що диктує необхідність обов'язкового носіння головного убору в біотопах кліщів.

4. Встановлено, що 12,3 \% іксодових кліщів, видалених від дітей, інфріковані B. burgdorferi sensu lato. наук.-практ. конфр. інфрекціоністів і пленуму ГО ВАІ (5-6.10.17 р., Житомир). - Тернопіль: ТДМУ, Укрмедкнига, 2017. - С. 9-11.

5. Акимов И.А. Иксодовые клещи городских ландшафтов г. Киева / И.А. Акимов, И.В. Небогаткин. - Киев, 2016. - 156 с.

6. Awareness of tick-borne bacterial infection in the students of non-medical universities in Ternopil region (Western Ukraine) / S. Nykytyuk, A. Pańczuk, M. Shkilna [et al.] // Health Problems of Civilization. - 2017. - Vol. 11, Issue 2. - P. 99-102.

7. Шкільна М.І. Обізнаність студентів немедичних університетів Тернополя щодо Лайм-бореліозу / М.І. Шкільна // Інфекційні хвороби сучасності. Етіологія, епідеміологія, діагностика, лікування, профілактика, біологічна безпека: матеріали наук.-практ. конф. 3 
міжнародною участю, присвяченої щорічним «Читанням» пам'яті академіка Л.В. Громашевського, приуроченої до 130-річчя від дня його народження (12-13 жовтня 2017 р.). - Київ, 2017. - С. 218-219.
8. Prevalence of tick-borne pathogens in Ixodes ricinus and Dermacentor reticulatus picks from different geographical locations in Belarus / A.L. Reye, V. Stegniy, N.P. Mishaeva // PLoS One. - 2013. - Vol. 8, N 1. - P. 544-576.

\section{References}

1. Andreichyn, M.A. (Ed.). (2007). Infektsiini khvoroby u zahalnii praktytsi ta simeinii medytsyni [Infectious diseases in general practice and family medicine]. Ternopil: TDMU, Ukrmedknyha [in Ukrainian]

2. Vasylieva, N.A., Ivakhiv, O.L., Kachor, V.O., Avsiukevych, O.Ye, Voloshyn, S.B., Prodan, A.M., ... \& Semenyshyn, O.B. (2011). Khvoroba Layma na Ternopilshchyni [Lime-disease in Ternopil region]. Infektsiini khvoroby - Infectious Diseases, 2, 50-53 [in Ukrainian].

3. Shkilna, M.I. (2016). Laim-borelioz u pratsivnykiv lisovykh hospodarstv Ternopilskoi oblasti [Lyme-borreliosis in forestry workers of Ternopil region]. Infektsiini khvoroby - Infectious Diseases, 1 (83), 36-40 [in Ukrainian].

4. Andreichyn, M.A., Shkilna, M.I., Nykytiuk, S.O., Podobivskyi, S.S., Marchuk, O.M., Klishch, I.M., \& Korda, M.M. (2017). Chastota vyiavlennia borelii i anaplazmy u klishchiv, vyluchenykh vid meshkantsiv Ternopilskoi oblasti [Frequency of discovering of borelli and anaplasma in ticks extracted from citizens of Ternopil region]. Epidemiolohichni ta klinichni uskladnennia infektsiinykh i parazytarnykh khvorob u suchasnykh umovakh: tezy vseukr. nauk.-prakt. konf. infektsionistiv i plenumu HO VAI (5-6.10.17, Zhytomyr). Ternopil: TDMU, Ukrmedknyha [in Ukrainian].

\section{SCREENING STUDY OF PARENTS' KNOWLEDGE ABOUT LYME BORRELIOSIS WHOSE CHILDREN SUFFERED FROM THE ATTACK OF TICKS}

\author{
S.O. Nykytyuk, M.A. Andreychyn \\ I. Horbachevsky Ternopil State Medical University
}

SUMMARY. The aim of the work - to evaluate parents' knowledge about Lyme borreliosis whose children suffered from the attack of ticks at the territory of Ternopil region and define the frequency of natural infection of $B$. Burgdorferi sensu lato of ticks extracted from citizens of the region.

Patients and methods. 207 parents were interrogated. All of them answered the questions from the uniform international questionnaire. The parents' knowledge about Lyme Borreliosis whose children suffered from the attack of ticks has been analyzed and evaluated. The expediency of dissemination of their knowledge
5. Akimov, I.A., \& Nebogatkin, I.V. (2016). Iksodovye kleshchi gorodskikh landshaftov g. Kiyeva [Ixodic ticks of town landscapes in Kyiv]. Kyiv [in Russian].

6. Nykytyuk, S., Pańczuk, A., Shkilna, M., Tokarska-Rodak, M., Szepeluk, A., Melnyk, L., \& Korda, M. (2017). Awareness of tickborne bacterial infection in the students of non-medical universities in Ternopil region (Western Ukraine). Health Problems of Civilization, 11, 2, 99-102.

7. Shkilna, M.I. (2017). Obiznanist studentiv nemedychnykh universytetiv Ternopolia shchodo Laim-boreliozu [Awareness of Lymeborreliosis in students of non-medical universities in Ternopil]. Infektsiini khvoroby suchasnosti. Etiolohiia, epidemiolohiia, diahnostyka, likuvannia, profilaktyka, biolohichna bezpeka: materialy naukovopraktychnoi konferentsii z mizhnarodnoiu uchastiu, prysviachenoi shchorichnym «Chytanniam» pamiati akademika L.V. Hromashevskoho pryurochenoi do 130 richchia vid dnia yoho narodzhennia», 12-13 zhovtnia 2017. Kyiv [in Ukrainian].

8. Reye, A.L., Stegniy, V., Mishaeva, N.P. (2013). Prevalence of tick-borne pathogens in ixodes ricinus and dermacentor reticulatus ticks from different Geographical Locations in Belarus. PLoS One, 8(1), 544-576

about this disease and other infections caused by ticks' bites has been proved.

Research results. 38 (18.36\%) children suffered in the village, 94 (45.41\%) - in the town; 48 (23.19\%) - in the forest; on meadow 11 (5.31\%); 16 (7,73.3\%) - do not remember.

50 persons were bitten in their head and 40 persons were bitten in their legs. Bites in the hands, neck and trunk from behind were mentioned less often -24 persons were bitten in their hands, 34, 21 persons were bitten in their necks and 25 persons were bitten in their trunk.

$87.0 \%$ of the parents interviewed do not use repellents at the entrance to the forest zone, inspect the skin after returning from the forest only $33.6 \%$ of the respondents $70.0 \%$ of ticks were extracted by doctors in Ternopil Children's Hospital and $70.0 \%$ of interrogated acepticized the locus of bite using anti-infective agent, the rest of ticks were extracted by other method. 


\section{ОРИГІНАЛЬНІ ДОСЛІДЖЕННЯ}

Conclusions. $22.4 \%$ of interrogated parents used repellents visiting forests and parks and $65.0 \%$ of interrogated persons observe their body after visiting forests and parks.

These data show the law level of knowledge about the measures of prophylaxis, the right way of extraction of ticks and the expediency of the examination of the suffered people from ticks' attacks and the infected ones by Borrelia.

Children were often bitten by ticks in their heads that shows the necessity of wearing hats in the biotopes of ticks.

In $12.3 \%$ of Lyme's ticks, which were extracted from children, were found out infection of B. Burgdorferi sensu lato.

Key words: Lyme borreliosis; Borrelia; diagnostics; ticks; questionnaire; repellents.

\section{Відомості про авторів:}

Никитюк Світлана Олександрівна - к. мед. н., доцент касредри педіатрії № 2 Тернопільського державного медичного університету ім. І.Я. Горбачевського; androx@tdmu. edu.ua
Андрейчин Михайло Антонович - академік НАМНУ, д. мед. н., завідувач касредри інфекційних хвороб з епідеміологією, шкірними і венеричними хворобами Тернопільського державного медичного університету ім. І.Я. Горбачевського; andreychyn@tdmu.edu.ua

\section{Information about autors:}

Nykytiuk S. - PhD, Associated Professor of the Department of Pediatrics No. 2 of I. Horbachevsky Ternopil State Medical University; androx@tdmu.edu.ua

Andreichyn M. - academician of the NAMS of Ukraine, $M D$, head of the Department of Infectious Diseases and Epidemiology, Dermatology and Venereology of I. Horbachevsky Ternopil State Medical University; andreychyn@tdmu.edu.ua

Конфрлікт інтересів: немає.

Authors have no conflict of interest to declare.

Отримано 2.02.2018 p. 